\title{
Introduction to the special issue on the 2016 Meinong, Taiwan, earthquake
}

\author{
Ruey-Juin Rau ${ }^{1, *}$ and Wen-Tzong Liang ${ }^{2}$ \\ ${ }^{1}$ Department of Earth Sciences, National Cheng Kung University, Tainan City, Taiwan \\ ${ }^{2}$ Institute of Earth Sciences, Academia Sinica, Taipei City, Taiwan
}

Received 6 June 2017, Accepted 7 June 2017

Keywords: 2016 Meinong earthquake, Source rupture model, Seismic hazard potential

Citation: Rau, R.-J. and W.-T. Liang, 2017: Introduction to the special issue on the 2016 Meinong, Taiwan, earthquake. Terr. Atmos. Ocean. Sci., 28, I-III, doi: 10.3319/TAO.2017.06.07.01

Right after the 2010 Chiashian earthquake, there have been five $\mathrm{M} \sim 6$ mid- to lower crust events occurred inland Taiwan, in which the 2016 Meinong earthquake is the most devastated. The 6 February $2016 \mathrm{M}_{\mathrm{L}} 6.4$ Meinong earthquake (03:57:27 local time) occurred at about $35 \mathrm{~km}$ ESE of the Tainan city with a focal depth of $16.7 \mathrm{~km}$. It is a moderatesized event, however, produced widespread strong shaking in the $35-\mathrm{km}$-away Tainan city and caused about 10 buildings collapsed and 117 death. In addition, significant aftershocks occurred right beneath the Tainan city with focal depths reaching $30 \mathrm{~km}$ at the lower crust, which has never been observed in inland SW Taiwan. The Taiwan Earthquake Model (TEM) announced a seismic hazard map of Taiwan in the end of 2015 and indicated a relatively high seismic hazard in Tainan (Rau and Ma 2016; Wang et al. 2016). Although the TEM model does not account for the blind faults as shown by the 2016 Meinong event, such an event occurred at this location was considered as an area source in the TEM model and the extremely high strain rate, $\sim 10^{-6}$ in SW Taiwan anticipates the reactivations of any pre-existing structures in this highly deformed crust. The scientific uniqueness and unexpectedly severe hazard in Tainan drive us to better understand the nature of the 2016 Meinong earthquake sequence in both scientific and engineering aspects.

With our efforts on the 2016 Meinong event in SW Taiwan, we wish to improve our understanding of the nature of mid- to lower crustal seismicity in the transition from subduction to collision tectonic regime in southern Taiwan. With the contributions of this special issue, we have collected 11 papers documenting the efforts on the research of the 2016 Meinong event, which can not only provide an opportunity for the discussion of research results, but also promote the emphasis of the earthquake disaster prevention policy by the governments.

Kanamori et al. (2017) investigated the overall charac-

\footnotetext{
* Corresponding author

E-mail:raurj@mail.ncku.edu.tw
}

teristics of the 2016 Meinong earthquake by inverting the source model and analyzing the ground motion variability considering the radiation pattern, site and propagation effects and directivity. They concluded that if these three effects work together to generate ground motions, the extremely large $S$ pulse observed in Tainan can occur even for a moderate event. Wen et al. (2017) relocated the earthquake locations and determined the focal mechanisms and hence the stress state for the 2016 Meinong earthquake sequences. Furthermore, they used the strong motion data to invert the source rupture model. By integrating all these information, they concluded that multiple pre-existing blind faults were reactivated during the 2016 Meinong earthquake sequences. Based on surface and subsurface geology and geodetic observations during the 2016 Meinong earthquake, Le Béon et al. (2017) built two E-W balanced cross-sections to identify the shallow structures that may have been reactivated during the earthquake. They interpreted these activated structures as a series of west-dipping back-thrust ramps connected to the westward-propagating Tainan detachment.

Liu et al. (2017) installed 10 QuakeFinder systems (magnetometer, infrasound, geophone, and conductivity/ temperature/humidity sensors) co-located with nearby Central Weather Bureau strong motion seismic stations in the Taiwan Island and detected co-seismic signals of the Meinong earthquake from magnetometer, infrasound, and geophone sensors. Kuo-Chen et al. (2017) deployed 36 vertical $4.5 \mathrm{~Hz}$ geophones with about $5-\mathrm{km}$ station spacing in the Meinong source area for one month period after the mainshock. They processed these data and used the ambient noise tomography method to construct a 3-D shear wave velocity model for the upper $5 \mathrm{~km}$ in the source region. They found that the co-seismic uplift region shown by InSAR and GPS results is coincide with the low S-wave velocity area.

Lee et al. (2017) validated the occurrence of the 2016 Meinong earthquake in the TEM PSHA2015 model (Wang et al. 2016) and demonstrated that the strong shaking Tainan area is located at the high seismic potential zone 
in the model and the Meinong event is considered as the area source in the PSHA2015 model. However they emphasized that the Meinong event did release about $16 \%$ of total seismic hazard potential for the 475 years return period; the seismic hazard potential remains high in southern Taiwan. Liu (2017) calculated the maximum PGA ShakeMap for $\mathrm{M}_{\mathrm{w}} 6.8$ - 7.2 scenario earthquakes occurred on the Chishan fault in southern Taiwan and discussed the resulted hazard and possible human fatalities in the major cities Kaohsiung and Tainan. Based on the simulation results, he urged the government to take effective actions on seismic hazard mitigation measures in the highly urbanized Kaohsiung and Tainan cities.

Wen and Chen (2017) analyzed the seismicity rate variations in the 2016 Meinong earthquake source area before the mainshock occurred and found a seismic quiescence period near the Meinong source zone soon after the 2012 Wutai earthquake occurred. This provides a useful information for earthquake hazard assessment. Chen et al. (2017) examined the relationship between the statistical indexes of the geo-electric fields observed in Taiwan and the occurrence of the 2016 Meinong earthquake and developed an earthquake-forecasting model for the observed geo-electric anomalies. Tsai et al. (2017) calculated the baseline length changes starting from 2007 for the GPS stations in the source region of the 2016 Meinong earthquake and found eight baselines indicating decreases of both shortening and lengthening rate nine months to two years before the Meinong earthquake. They considered this anomalous strain rate change as the pre-seismic precursor for the Meinong earthquake. By inspecting continuous recording of the soil gas composition variations, Fu et al. (2017) found the soil radon concentration increased at about two weeks before the Meinong event at the southern Taiwan stations and proposed that the observed radon concentration anomalies may represent a pre-seismic precursor for a large earthquake.

Through the collections of this issue, we wish to improve our understanding on the characteristics and nature of the 2016 Meinong earthquake, and emphasize taking necessary actions on seismic hazard mitigation measures if such moderate-to-large earthquakes occurred in western Taiwan.

Acknowledgements We wish to thank all the authors who contributed to this special issue and we express our gratitude to many reviewers who provided thorough and insightful comments to the manuscripts. This preface was supported by Ministry of Science and Technology under grants MOST 106-2119-M-006-012.

\section{REFERENCES}

Chen, H.-J., C.-C. Chen, G. Ouillon, and D. Sornette, 2017: Using geoelectric field skewness and kurtosis to forecast the 2016/2/6, $\mathrm{M}_{\mathrm{L}} 6.6$ Meinong, Taiwan Earth- quake. Terr. Atmos. Ocean. Sci., 28, 745-761, doi: 10.3319/TAO.2016.11.01.01. [Link]

Fu, C.-C., V. Walia, T. F. Yang, L.-C. Lee, T.-K. Liu, C.-H. Chen, A. Kumar, S.-J. Lin, T.-H. Lai, and K.-L. Wen, 2017: Preseismic anomalies in soil-gas radon associated with 2016 M 6.6 Meinong earthquake, Southern Taiwan. Terr. Atmos. Ocean. Sci., 28, 787-798, doi: 10.3319/TAO.2017.03.22.01. [Link]

Kanamori, H., L. Ye, B.-S. Huang, H.-H. Huang, S.-J. Lee, W.-T. Liang, Y.-Y. Lin, K.-F. Ma, Y.-M. Wu, and T.-Y. Yeh, 2017: A strong-motion hot spot of the 2016 Meinong, Taiwan, earthquake $\left(\mathrm{M}_{\mathrm{w}}=6.4\right)$. Terr. Atmos. Ocean. Sci., 28, 637-650, doi: 10.3319/ TAO.2016.10.07.01. [Link]

Kuo-Chen, H., K.-X. Chen, W.-F. Sun, C.-W. Ho, Y.H. Lee, Z.-K. Guan, C.-C. Kang, and W.-Y. Chang, 2017: 3D Vs ambient noise tomography of the 2016 $\mathrm{M}_{\mathrm{w}}$ 6.4 Meinong Earthquake source region in Taiwan. Terr. Atmos. Ocean. Sci., 28, 693-701, doi: 10.3319/ TAO.2016.12.28.01. [Link]

Le Béon, M., M.-H. Huang, J. Suppe, S.-T. Huang, E. Pathier, W.-J. Huang, C.-L. Chen, B. Fruneau, S. Baize, K.-E. Ching, and J.-C. Hu, 2017: Shallow geological structures triggered during the $\mathrm{M}_{\mathrm{w}}$ 6.4 Meinong earthquake, southwestern Taiwan. Terr. Atmos. Ocean. Sci., 28, 663-681, doi: 10.3319/TAO.2017.03.20.02. [Link]

Lee, Y.-T., Y.-J. Wang, C.-H. Chan, and K.-F. Ma, 2017: The 2016 Meinong earthquake to TEM PSHA2015. Terr. Atmos. Ocean. Sci., 28, 703-713, doi: 10.3319/ TAO.2016.12.28.02. [Link]

Liu, J.-Y., C.-H. Chen, T.-Y. Wu, H.-C. Chen, K. Hattori, I.-C. Yang, T. Bleier, K. Kappler, Y. Xia, W. Chen, and Z. Liu, 2017: Co-seismic signatures in magnetometer, geophone, and infrasound data during the Meinong Earthquake. Terr. Atmos. Ocean. Sci., 28, 683692, doi: 10.3319/TAO.2017.03.05.01. [Link]

Liu, K.-S., 2017: Estimation of seismic ground motions and attendant potential human fatalities from scenario earthquakes on the Chishan fault in southern Taiwan. Terr. Atmos. Ocean. Sci., 28, 715-737, doi: 10.3319/ TAO.2017.01.06.01. [Link]

Rau, R.-J. and K.-F. Ma, 2016: Preface to the special issue on "Taiwan Earthquake Model: Seismic hazard assessment and earthquake scenario". Terr. Atmos. Ocean. Sci., 27, I-III, doi: 10.3319/TAO.2016.06.01.01(TEM). [Link]

Tsai, M.-C., T.-C. Shin, and K.-W. Kuo, 2017: Pre-seismic strain anomalies and coseismic deformation of Meinong earthquake from continuous GPS. Terr. Atmos. Ocean. Sci., 28, 763-785, doi: 10.3319/TAO.2017.04.19.01. [Link]

Wang, Y.-J., C.-H. Chan, Y.-T. Lee, K.-F. Ma, J. B. H. Shyu, R.-J. Rau, and C.-T. Cheng, 2016: Probabilistic seismic hazard assessment for Taiwan.Terr.Atmos.Ocean.Sci., 
27, 325-340, doi: 10.3319/TAO.2016.05.03.01(TEM). [Link]

Wen, S., Y.-L. Yeh, Y.-Z. Chang, and C.-H. Chen, 2017: The seismogenic process of the 2016 Meinong earthquake, southwest Taiwan. Terr. Atmos. Ocean. Sci.,
28, 651-662, doi: 10.3319/TAO.2017.02.17.01. [Link] Wen, Y.-Y. and C.-C. Chen, 2017: Seismicity variations prior to the $2016 \mathrm{M}_{\mathrm{L}}$ 6.6 Meinong, Taiwan earthquake. Terr. Atmos. Ocean. Sci., 28, 739-744, doi: 10.3319/ TAO.2016.12.05.01. [Link] 